\title{
Biological Monitoring of Air Pollutants and Its Influence on Human Beings
}

\author{
Shihong Cen*
}

Zhengzhou University of Industrial Technology, China

\begin{abstract}
Monitoring air pollutants via plants is an economic, convenient and credible method compared with the traditional ways. Plants show different damage symptoms to different air pollutants, which can be used to determine the species of air pollutants. Besides, pollutants mass concentration scope can be estimated by the damage extent of plants and the span of polluted time. Based on the domestic and foreign research, this paper discusses the principles, mechanism, advantages and disadvantages of plant-monitoring, and exemplifies plenty of such plants and the minimum mass concentration and pollution time of the plants showing damage symptoms. Finally, this paper introduces the effects of air pollutants on immune function of the human body, such as decrease of the body's immune function, decline of lung function, respiratory and circulatory system changes, inducing and promoting human allergic diseases, respiratory diseases and other diseases.
\end{abstract}

Keywords: Air pollutants, biological monitoring, damage symptoms, health, plants.

\section{INTRODUCTION}

In recent years, with the increase of traffic congestion and industrial waste gas emissions of road vehicles, a number of large and medium-sized cities' air quality gradually declined, coupled with the frequent occurrence of fog and haze, thus air pollution is becoming more and more serious an issue [1]. Currently, people can't accomplish at one stroke to improve the air quality by increasing the investment in improving the air quality. People can only follow the prescribed order to conduct rigorous testing of atmospheric pollutants, in order to understand and master the air quality and related issues of people's contact at any time.

\section{CONCEPT AND BASIC CONTENT OF AIR POL- LUTION AND ENVIRONMENTAL MONITORING}

\subsection{Air pollution, Air Pollutants and Total Quantity Control of the Pollutant Exposition}

Air pollution, as the name implies, refers to the number of harmful substances in the atmosphere of concentration and residence time more than the allowed range of atmospheric environment, which is beyond the capability of diffusion and dilution of the air, deteriorates the air quality, and brings about bad influence directly or indirectly to human health and ecological environment. Atmospheric pollution is produced by natural processes marked by human activities causing pollution to the atmospheric environment. This study is mainly focused on: the pollutants produced by human activities including industrial and agricultural production, daily life and the means of transport; the total amount of pollutants; control with reference to a region; closely monitoring and control of the total emission of air pollutants discharged

*Address correspondence to this author at the Zhengzhou University of Industrial Technology, China; Tel: +86-13253565366;

E-mail:348405109@qq.com into the region in a certain period of time, so that the air dilution and diffusion, and atmospheric environment pollution can be estimated [2].

\subsection{Air Pollution Sources and Some Common Air Pollu- tants}

Some common air pollutants are suspended particles mainly including: SO2, PM2.5, NOX, CO, VOCS (Volatile Organic Compounds), heavy metal, radioactive substances, photochemical oxide, etc. The major cause of these air pollutants are the factors of the discharge of pollutants exceeding the atmospheric saturation, pollutants pollution emission height distance, air self-purification ability etc. Table 1 shows pollutants in different times over different concentrations, which will lead to air pollution.

\subsection{Environmental Monitoring}

Environmental monitoring means intermittent detection of air pollutants, pollution sources and other contents by the department of environmental monitoring, in order to forecast the environmental problems for prevention planning.

\section{BIOLOGICAL MONITORING OF AIR POLLU- TANTS}

Through the continuous observation and study, it is found that some plants show some reaction to harmful gases, which can be used as a biological indicator for certain plants to monitor atmosphere. Plants under different air pollutants harm will exhibit different symptoms. These symptoms can be used to judge the type of atmospheric pollutants, and to estimate its concentration range according to the damage extent to plants and the time of pollution [3]. Compared with the traditional monitoring method, using plants to monitor air pollutants is an economic, simple and reliable method. 
Table 1. The average concentration of air pollutants at different time.

\begin{tabular}{|c|c|c|c|}
\hline Air pollutants & Mean time & $\begin{array}{l}\text { Primary concentration limit on average } \\
\qquad / \mu \mathrm{g} \cdot \mathrm{m}^{-3}\end{array}$ & $\begin{array}{l}\text { Secondary concentration limit on average } \\
\qquad / \mu \mathrm{g} \cdot \mathrm{m}^{-3}\end{array}$ \\
\hline \multirow[t]{3}{*}{$\mathrm{SO}_{2}$} & $1 \mathrm{~h}$ & 150 & 500 \\
\hline & $24 \mathrm{~h}$ & 50 & 150 \\
\hline & $1 \mathrm{a}$ & 20 & 60 \\
\hline $\mathrm{NO}_{2}$ & $1 \mathrm{a}$ & 40 & 40 \\
\hline \multirow[t]{2}{*}{$\mathrm{CO}$} & $1 \mathrm{~h}$ & 10 & 10 \\
\hline & $24 \mathrm{~h}$ & 4 & 4 \\
\hline $\mathrm{PM}_{10}$ & $1 \mathrm{a}$ & 40 & 70 \\
\hline \multirow[t]{2}{*}{$\mathrm{PM}_{2.5}$} & $24 \mathrm{~h}$ & 35 & 75 \\
\hline & $1 \mathrm{a}$ & 15 & 35 \\
\hline
\end{tabular}

\subsection{The Principle of Biological Monitoring}

\subsubsection{The Mechanism of Monitoring Air Pollutants by Plants}

The basic principle of monitoring air pollutants by plants is through using the biological effect of air pollutants on the plants. That is to say, the damage symptoms of plants, mainly the leaves, are related with the types, concentration and contacting time of pollutants. Air pollution situation, especially the types of air pollutants, is evaluated by the community types of the injured plants and symptoms of the damage. Moreover, the concentration of pollutants is measured by the victimization levels and contamination time of plants.

Atmospheric pollutants enter the plants through leaf stomata. The leaf is an important part of a plant, and is the main organ for photosynthesis and transpiration. Air pollutants can directly damage plant leaves. The victimization levels are directly related with that whether air pollutants coming into stomata or not and how much. It is monitored from symptoms of plants that which kind and how much concentration of harmful gas [4].

\subsubsection{Symptoms of Endangered Plants by Several Kinds of Harmful Air Pollutants}

The damage symptoms of plants caused due to several main pollutants in the atmosphere are shown in Table 2.

\subsubsection{Monitoring of Concentration Plant}

Plants that can be used to monitor SO2 are alfalfa, sesame, moss, spinach, carrot, sweet potato, cucumber, oat, soybean, cotton, tobacco, pepper, Zinnia, wheat, red sage, rose, chrysanthemum, carnation, apple tree, Chinese rose, silk tree, plum, sycamore, poplar, birch, pine, cedar, larch, etc. It was monitored that when the atmospheric $\mathrm{SO}_{2}$ concentration was $3.4 \mathrm{mg} / \mathrm{m}^{3}$, symptoms of alfalfa and sesame were visible after being exposed for one hour; and when the atmospheric $\mathrm{SO}^{2}$ concentration was $0.14 \sim 1.4 \mathrm{mg} / \mathrm{m}^{3}$, symptoms of spinach, cucumber and oats were visible after being exposed for 8 hours, or $3 \sim 11 \mathrm{mg} / \mathrm{m}^{3}$ for 30 minutes.

Gladiolus is the most commonly used plant for monitoring fluoride [5]. It will be damaged by $9 * 10^{-4} \mathrm{mg} / \mathrm{m}^{3} \mathrm{HF}$ when exposed for $2 \sim 3 \mathrm{~h}$ or by $9 * 10^{-3} \mathrm{mg} / \mathrm{m}^{3}$ when exposed for $20 \mathrm{~min}$. In addition, apricot, plum, grape, tulip, garlic, jade hairpin, moss, tobacco, buckwheat, corn, tomato, mango, peach, peach tree, elm, cedar and other plants can also be used for monitoring of fluoride.

$\mathrm{O}_{3}$ can be monitored by tobacco, tomato, pea, spinach, oat, crab grass, peanut, lilac, peony, radish, muskmelon and American pine. When the mass concentration of $\mathrm{O}_{3}$ in the atmosphere reaches $0.1 * 10^{-3}$ to $0.26 * 10^{-3} \mathrm{mg} / \mathrm{m}^{3}$ for $2 \sim 4$ $\mathrm{h}$, these plants will show symptoms.

PAN can be monitored by Petunia, chickweed, bluegrass, lettuce, bean, tomato, tobacco, mustard, etc. When the mass concentration of PAN in the atmosphere is $0.4 \sim 0.5 \mathrm{mg} / \mathrm{m}^{3}$, there will be visible symptoms after $4 \mathrm{~h}$.

$\mathrm{NO}_{2}$ can be monitored by tobacco, oat, wheat, corn, carrots, tomato, potato, onion, bean, Citrus, melon and so on. Under weak light, these plants will show symptoms when

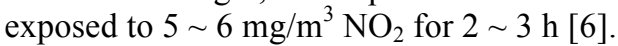

Chlorine and chloride can be monitored by Acer negundo, larch, Pinus tabuliformis, kapok, fake forsythia, apple, peach, alfalfa, barley, buckwheat, corn, cabbage, spinach, radish, leek, onion, tomato, melon, beans, sunflower, etc. These plants will show symptoms when the content of $\mathrm{Cl}_{2}$ in the air reaches $0.15 \sim 3 \mathrm{mg} / \mathrm{m}^{3}$ and lasts for $3 \sim 5 \mathrm{~h}$. 
Table 2. Symptoms of endangered plants by several kinds of harmful air pollutants.

\begin{tabular}{|c|c|c|c|c|c|}
\hline Air pollutants & Damage mechanism & Injury spot area & Injury spot shape & $\begin{array}{l}\text { Injury spot } \\
\text { color }\end{array}$ & $\begin{array}{l}\text { Age and degree of the } \\
\text { damaged leaf }\end{array}$ \\
\hline $\mathrm{SO}_{2}$ & $\begin{array}{l}\text { Induce plasmolysis of spongy cells } \\
\text { and palisade cells, then shrink or } \\
\text { collapse, chlorophyll decomposition }\end{array}$ & $\begin{array}{l}\text { Mainly pulse, occasionally } \\
\text { leaf margin }\end{array}$ & $\begin{array}{l}\text { Irregular points, } \\
\text { block, clear bounda- } \\
\text { ries }\end{array}$ & $\begin{array}{l}\text { Brown, red } \\
\text { brown }\end{array}$ & $\begin{array}{l}\text { Expanded leaves }>\text { old } \\
\text { leaves and mature leaves } \\
>\text { unfolded leaves }\end{array}$ \\
\hline fluoride & $\begin{array}{l}\text { Induce plasmolysis of mesophyll and } \\
\text { cell }\end{array}$ & $\begin{array}{l}\text { Mainly leaves and margin, } \\
\text { occasionally pulse }\end{array}$ & A strip or band & Pale brown & $\begin{array}{c}\text { Young leaves }>\text { mature } \\
\text { leaf }>\text { old leaf }\end{array}$ \\
\hline $\mathrm{O}_{3}$ & $\begin{array}{l}\text { Destruct cell wall of palisade tissue } \\
\text { and epidermal cells, oxidize glucose }\end{array}$ & $\begin{array}{l}\text { Mainly leaf surface, occa- } \\
\text { sionally pulse }\end{array}$ & $\begin{array}{l}\text { Scattered dense } \\
\text { punctate }\end{array}$ & Brown, tawny & $\begin{array}{l}\text { Mature leaves }>\text { young } \\
\text { leaves }>\text { old leaves }\end{array}$ \\
\hline $\begin{array}{l}\text { Peroxyacyl ni- } \\
\text { trates(PAN) }\end{array}$ & $\begin{array}{l}\text { Induce leaves to shrink, loss water, } \\
\text { and then be filled into the air }\end{array}$ & $\begin{array}{l}\text { Mainly blade back, occa- } \\
\text { sionally leaf tip }\end{array}$ & Glass, necrotic zone & $\begin{array}{l}\text { Silvery white, } \\
\text { brown, } \tan \end{array}$ & $\begin{array}{l}\text { Young leaves tip and old } \\
\text { leaves base vulnerable }\end{array}$ \\
\hline $\mathrm{NO}_{2}$ & Break cell & Pulse & $\begin{array}{l}\text { Irregular spot or } \\
\text { whole leaf spot }\end{array}$ & $\begin{array}{l}\text { White, tawny, } \\
\text { brown }\end{array}$ & Young leaves vulnerable \\
\hline
\end{tabular}

\subsection{Monitoring Methods}

\subsubsection{Determining Atmospheric Pollution According to the Visible Symptoms}

(1) (1) Monitoring air pollution using indicator plants to guard. For instance, planting a variety of different sensitive plants around the plant, not only will beautify the environment but also monitor the pollution of the environment.

(2) (2) Estimating the level of air pollution by plant communities. Because of the different level of sensitivity to the pollution, the reaction of different kind of plants in the community is significantly different to the air pollution. Table 3 shows the survey results on the plant community around chemical factories which had SO2 emission [7].

Table 3. Plants situation around $30 \sim 50 \mathrm{~m}$ of chemical factories.

\begin{tabular}{|l|l|}
\hline Plant & Situation \\
\hline \hline $\begin{array}{l}\text { Hung ling wood, poplar, Cana- } \\
\text { da, Sabina chinensis, towel } \\
\text { gourd }\end{array}$ & $\begin{array}{l}\text { Above } 80 \% \text { leaves suffered and even } \\
\text { fell off, leaves had obvious large } \\
\text { scars, part of the plants died. }\end{array}$ \\
\hline $\begin{array}{l}\text { Sunflower, onion, corn, chry- } \\
\text { santhemum, morning glory }\end{array}$ & $\begin{array}{l}\text { About 50\% foliar surface was dam- } \\
\text { aged, there were point and block- } \\
\text { shaped scars between leaf veins }\end{array}$ \\
\hline $\begin{array}{l}\text { Chinese rose, rose, Chinese } \\
\text { wolfberry, cedar, cypress }\end{array}$ & $\begin{array}{l}\text { About 30\% foliar surface was dam- } \\
\text { aged, there were a little few point and } \\
\text { block-shaped scars between leaf } \\
\text { veins }\end{array}$ \\
\hline $\begin{array}{l}\text { Grape, honeysuckle, medlar, } \\
\text { purslane }\end{array}$ & $\begin{array}{l}\text { About 10\% foliar surface was dam- } \\
\text { aged, there were a little few point - } \\
\text { shaped scars between leaf veins }\end{array}$ \\
\hline $\begin{array}{l}\text { Magnolia, big leaf boxwood, } \\
\text { gardenia, wintersweet }\end{array}$ & No obvious symptoms \\
\hline
\end{tabular}

\subsubsection{Using Lichens to Monitor Air Pollution}

Lichens are symbiotic bacteria and algae, most of which can endure the harsh environmental conditions. However, they are sensitive to $\mathrm{SO}_{2}, \mathrm{H}_{2} \mathrm{~S}$ and other air pollutants. And even a small amount of toxic substances can affect their growth, and induce their death [8].

We can investigate lichen species to find the number and distribution around the contaminated area to estimate the pollution concentration. Table $\mathbf{4}$ is a survey for genus, species and number of lichens at different distances from a factory [9].

Table 4. An investigation for genus, species and number of lichens at different distances from a factory.

\begin{tabular}{|c|c|c|c|}
\hline $\begin{array}{c}\text { Sampling } \\
\text { number }\end{array}$ & $\begin{array}{c}\text { Distance from } \\
\text { the factory } / \mathbf{m}\end{array}$ & $\begin{array}{c}\text { Number of } \\
\text { genus }\end{array}$ & $\begin{array}{c}\text { Number of } \\
\text { species }\end{array}$ \\
\hline \hline A & 100 & 3 & 5 \\
\hline B & 450 & 3 & 7 \\
\hline C & 1100 & 4 & 9 \\
\hline D & 1350 & 5 & 11 \\
\hline E & 1600 & 7 & 15 \\
\hline F & 2600 & 9 & 26 \\
\hline G & 6500 & 12 & 39 \\
\hline
\end{tabular}

\subsubsection{Using Moss to Monitor Air Pollution}

Moss is a sensitive indicator of plant next to the lichen. When exposed to air pollution, the moss will turn black or brown, which is an obvious phenomenon. Moss communities will decline seriously and the species diversity of moss will 
continue to decrease until disappear in the long-term pollution. Real et al. first used moss to monitor fluoride concentration in the environment [10].

\subsubsection{Estimating Pollution According to the Content of Toxicant In Plant Leaves}

Leaf is the main organ to absorb atmospheric pollutants. Therefore, determination of leaf content of pollutants can explain the contaminated area [11].

\subsubsection{Analysis by Tree Ring}

The tree ring can reflect the pollution history over several years, and an average tree ring contaminated is narrowed. Also the ring material was determined by X-ray, the pollution situation, the year, the proportion of serious pollution of the small wood.

\subsubsection{Other Monitoring Methods}

The changes of photosynthesis and other physiological indexes of plants can reflect the pollution of the atmospheric environment, such as the determination of plant photosynthesis capacity to produce oxygen and content of chlorophyll $a$.

\section{EFFECTS OF AIR POLLUTANTS ON HUMAN HEALTH}

Human health hazards of air pollution. Under low concentration and long-term air pollution, body's immune and lung function will decline, and respiratory and circulatory system will change, inducing and promoting human allergic diseases, respiratory diseases and other diseases $[12,13]$.

Inhalable particulate matter PM10 and fine particulate matter $\mathrm{PM}_{2.5}$ is the most harmful for health. They can enter into bronchial of lungs and deposit by breathing, long-term effect is the direct cause of bronchial inflammation, especially the chronic obstructive pulmonary disease; they can even enter through the alveolar into the blood, which is one of the major risk factors for cardiovascular disease and pulmonary heart disease. These fine particles are also the carrier of toxic and harmful ingredients, such as bacteria, virus, heavy metals and organic compounds, which are carcinogenic and will promote cancer [14-16].

$\mathrm{SO}_{2}$ is oxidized to acid mist in the air, which can produce acute stimulation on the human eye conjunctiva, nose and respiratory tract mucosa, and cause increased bronchoconstriction, airway resistance. Acid mist may cause lung inflammation and pulmonary edema in lung tissue. Patients whose pulmonary valves are insufficient, such as the elderly and children are particularly sensitive to the stimulation of $\mathrm{SO}_{2}$. It is harmful for chronic bronchitis, emphysema and chronic lower respiratory diseases such as chronic obstructive pulmonary disease (COPD) if in long-term effects [17].

NOx has low water solubility, and can invade the deep respiratory bronchioles and alveoli. After long-term inhalation, NOx will be oxidized by active substance oxidation surfactant, which produces nitrite and nitrate, and induces lung tissue corrosion and stimulation, causing Bronchiolitis obliterans and pulmonary edema. NOx is an important substance in the formation of photochemical smog. Smog which has strong oxidation can cause symptoms of damage to respiratory system and cardiovascular system, such as eye irri- tation, difficulty in breathing, headache, chest tightness and shortness of breath, which is more pronounced for some people who have heart disease and lung disease $[17,18]$.

\section{CONCLUSION}

Atmospheric pollution is closely related to people's life. Although we can using the biological method of monitoring air pollutants to take measures to prevent the disease, the most fundamental way for our health is that do everything you to reduce emissions of pollutants. Only in this way, environment will become cleaner, and our children will thrive under the blue sky and white clouds.

\section{CONFLICT OF INTEREST}

The author confirms that this article content has no conflict of interest.

\section{ACKNOWLEDGEMENTS}

Declared none.

\section{REFERENCES}

[1] S. Batterman, R. Ganguly, and P. Harbin, "High resolution spatial and temporal mapping of traffic-related air pollutants," International Journal of Environmental Research and Public Health, vol. 12, no. 4, pp. 3646-3666, 2015.

[2] X. L. Chou, "Discussing issues related with detection of air pollutants," Agriculture and Technology, vol. 34, no. 2, 206 \& 224, 2014. (in Chinese)

[3] M.E. Conti,and G. Cecchetti, "Biological monitoring: lichens as bioindicators of air pollution assessment - a review," Environmental Pollution, vol. 114, no. 3, pp. 471-492, 2001.

[4] R. Pesch, and W. Schroeder, "Mosses as bioindicators for metal accumulation: Statistical aggregation of measurement data to exposure indices," Ecological Indicators, vol. 6, no. 1, pp. 137-152, 2006.

[5] M. Zhou, G. He, Y. Liu, P. Yin, Y. Li, H. Kan, M. Fan, A. Xue, and M. Fan, "The associations between ambient air pollution and adult respiratory mortality in 32 major Chinese cities, 2006-2010," Environmental Research, vol. 137, pp. 278-286, 2015.

[6] X. Meng, L. Chen, J. Cai, B. Zou, C.F. Wu, Q. Fu, Y. Zhang, Y. Liu, and H. Kan, "A land use regression model for estimating the $\mathrm{NO}_{2}$ concentration in shanghai, China," Environmental Research, vol. 137, pp. 308-315, 2015.

[7] A.J. Cohen, R.H. Anderson, B. Ostro, K.D. Pandey, M. Krzyzanowski, N. Künzli, K. Gutschmidt, A. Pope, I. Romieu, J.M. Samet, and K. Smith, "The global burden of disease due to outdoor air pollution," Journal of Toxicology and Environmental HealthPart A, vol. 68, no. 13-14, pp. 1301-1307, 2005.

[8] S. Gombert, J. Asta, and M.R.D. Seaward, "Lichens and tobacco plants as complementary biomonitors of air pollution in the Grenoble area (Isere, southeast France)," Ecological Indicators, vol. 6, no. 2, pp. 429-443, 2006.

[9] C.Q. Niu, "Introduction to contribution of animal and plant to air pollution monitoring," Journal of Jinzhong Normal Junior College, vol. 17, no. 2, pp. 27-28, 2000. (in Chinese)

[10] C. Real, J.R. Aboal, J.A. Fernandez, and A. Carballeira, "The use of native mosses to monitor fluorine levels-and associated temporal variations-in the vicinity of an aluminium smelter," Atmospheric Environment, vol. 37, no. 22, pp. 3091-3102, 2003.

[11] Z.H. He, "Environmental monitoring," Beijing: China Agriculture Press, pp. 195-203, 1994.

[12] J. Zhang, T. Zhu, H. Kipen, G. Wang, W. Huang, D. Rich, P. Zhu, Y. Wang, S.E. Lu, P. Ohman-Strickland, S. Diehl, M. Hu, J. Tong, 
J. Gong, and D. Thomas, "Cardiorespiratory biomarker responses in healthy young adults to drastic air quality changes surrounding the 2008 Beijing Olympics," Research report Health Effects Institute, vol. 174, pp. 5-174, 2013.

[13] S. Mahalingaiah, J.E. Hart, F. Laden, K.L. Terry, R. BoyntonJarrett, A. Aschengrau, S.A. Missmer, "Air pollution and risk of uterine leiomyomata," Epidemiology, vol. 25, no. 5, pp. 682-688, 2014.

[14] F.S. Wei, and R.S. Chapman, "Research on influence of air pollution on respiratory health," China Environmental Science Press, 2001.

[15] A. Ukëhaxhaj, D. Gjorgjev, M. Ramadani, S. Krasniqi, T. Gjergji, and D. Zogaj, "Air pollution in Pristina, influence on cardiovascu- lar hospital morbidity," Medical Archives, vol. 67, no. 6, pp. 438441, 2013.

[16] M.A. Barrero, J.A. Orza, M. Cabello, and L. Cantón, "Categorisation of air quality monitoring stations by evaluation of $\mathrm{PM}_{10}$ variability," Science of The Total Environment, vol. 524-525, pp. 225236, 2015.

[17] F.Z. Cao, "China's environmental and health report," China Environmental Science Press, 1999.

[18] B.H. Chen, and H.D. Kan, "Method of health risk evaluation of urban air pollution-the harm of main air pollutants," Journal of Environment and Health, vol. 21, no. 3, pp. 67-69, 2004.

Received: April 10, 2015

(c) Shihong Cen; Licensee Bentham Open.

This is an open access article licensed under the terms of the (https://creativecommons.org/licenses/by/4.0/legalcode), which permits unrestricted, noncommercial use, distribution and reproduction in any medium, provided the work is properly cited. 